WSRC-TR-2001-00119 (U)

\title{
Spatial Variation of Soil Type and Soil Moisture in the Regional Atmospheric Modeling System (U)
}

\author{
Robert L. Buckley \\ Savannah River Technology Center
}

Publication Date: March 2001

Westinghouse Savannah River Company

Savannah River Site

Aiken, SC 29808

This document was prepared in connection with work done under Contract No. DE-AC09-96SR18500

with the U. S. Department of Energy 
This document was prepared in conjunction with work accomplished under Contract No.

DE-AC09-96SR18500 with the U.S. Department of Energy.

\section{DISCLAIMER}

This report was prepared as an account of work sponsored by an agency of the United States Government. Neither the United States Government nor any agency thereof, nor any of their employees, makes any warranty, express or implied, or assumes any legal liability or responsibility for the accuracy, completeness, or usefulness of any information, apparatus, product or process disclosed, or represents that its use would not infringe privately owned rights. Reference herein to any specific commercial product, process or service by trade name, trademark, manufacturer, or otherwise does not necessarily constitute or imply its endorsement, recommendation, or favoring by the United States Government or any agency thereof. The views and opinions of authors expressed herein do not necessarily state or reflect those of the United States Government or any agency thereof.

This report has been reproduced directl y from the best available copy.

Available for sale to the public, in paper, from: U.S. Department of Commerce, National Technical Information Service, 5285 Port Roy al Road, Springfield, VA 22161, phone: (800)

553-6847, fax: (703) 605-6900, email: orders@ntis.fedworld.gov online ordering: http://www.ntis.gov/ordering.htm

Available electronically at http://www.doe.gov/bridge

Available for a processing fee to U.S. Department of Energy and its contractors, in paper, from: U.S. Department of Energy, Office of Scientific and Tech nical Information, P.O. Box 62, Oak Ridge, TN 37831-0062, phone: (865 ) 576-8401, fax: (865) 576-5728, email: reports@adonis.osti.gov 
WSRC-TR-2001-00119

March 2001

DOCUMENT: $\quad$ WSRC-TR-2001-00119

TITLE:

Spatial Variation of Soil Type and Soil Moisture in the Regional Atmospheric Modeling System (U)

TASK:

TECHNICAL REVIEW

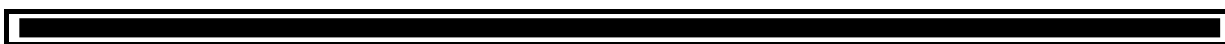

B. L. O'Steen

Date:

SRTC/Measurement Technology Department/Nonproliferation Technologies Section

\section{APPROVALS}

口PPROVALS

R. P. Addis, Manager, ATG

Date:

SRTC/Measurement Technology Department/Nonproliferation Technologies Section

A. L. Boni, Manager, NTS

Date:

SRTC/Measurement Technology Department/Nonproliferation Technologies Section 
WSRC-TR-2001-00119

March 2001

(Blank Page) 
WSRC-TR-2001-00119

March 2001

ABSTRACT

Soil characteristics (texture and moisture) are typically assumed to be initially constant when performing simulations with the Regional Atmospheric Modeling System (RAMS). Soil texture is spatially homogeneous and time-independent, while soil moisture is often spatially homogeneous initially, but time-dependent. This report discusses the conversion of a global data set of Food and Agriculture Organization (FAO) soil types to RAMS soil texture and the subsequent modifications required in RAMS to ingest this information. Spatial variations in initial soil moisture obtained from the National Center for Environmental Predictions (NCEP) large-scale models are also introduced. Comparisons involving simulations over the southeastern United States for two different time periods, one during warmer, more humid summer conditions, and one during cooler, dryer winter conditions, reveals differences in surface conditions related to increases or decreases in near-surface atmospheric moisture content as a result of different soil properties. Three separate simulation types were considered. The base case assumed spatially homogeneous soil texture and initial soil moisture. The second case assumed variable soil texture and constant initial soil moisture, while the third case allowed for both variable soil texture and initial soil moisture. The simulation domain was further divided into four geographically distinct regions. It is concluded there is a more dramatic impact on thermodynamic variables (surface temperature and dewpoint) than on surface winds, and a more pronounced variability in results during the summer period. While no obvious trends in surface winds or dewpoint temperature were found relative to observations covering all regions and times, improvement in surface temperatures in most regions and time periods was generally seen with the incorporation of variable soil texture and initial soil moisture. 
WSRC-TR-2001-00119

March 2001

TABLE OF CONTENTS

1. INTRODUCTION

2. BACKGROUND

2.1 Soils

2.2 Soil Moisture

2

3. IMPLEMENTATION IN RAMS

3.1 Soil Texture

3

3.2 Soil Moisture

4

4. APPLICATION

5. CONCLUSIONS

8

REFERENCES

9

APPENDIX: Modification to the RAMS code

31 


\section{LIST OF TABLES}

Table 1: Relation of soil texture to classification.

Table 2: FAO (1974) Major Soil Categories.

Table 3: Soil texture classification used in RAMS, version 3a.

Table 4: Conversion factor between FAO type and soil texture.

Table 5: Location of National Weather Service stations used in the modeling comparisons.

\section{LIST OF FIGURES}

Figure 1: Soil texture triangle showing the mass content of clay, silt and sand for the different soil texture types (adapted from USDA 1998).

Figure 2: Soil texture for the southeast United States using the mapping procedure.

Figure 3: Comparison of observed soil moisture [\%] and large-scale NCEP AVN and Eta numerical models at 24-hr increments over a one year period beginning 1 January 2000.

Figure 4: Measured precipitation from the SRS (using a tipping-bucket rain gauge co-located with the soil-moisture probe) during the months of June and December 2000 as totaled over a 24-hr period. Note that the precipitation scale is logarithmic, and the total precipitation for each month is indicated at the top of the figure.

Figure 5: Location of stations within the simulation domain and the labeling of different regions. There are 6 NWS stations labeled within each region. See Table 5 for a description of each location.

Figure 6: Eta-derived soil moisture for the period 1-29 June, 2000 as interpolated to the 6 NWS station locations for each region as labeled in Fig. 5.

Figure 7: Eta-derived soil moisture for the period 1-31 December, 2000 as interpolated to the 6 NWS station locations for each region as labeled in Fig. 5.

Figure 8: Wind direction as a function of forecast time in 2-hr increments for 1-29 June, 2000 as observed and simulated for each region. The average within each region is over the 6 NWS stations and over all 29 days. If observed data are missing, then results for that station and time are discarded.

T-C, M-C = Constant soil texture field, constant initial soil moisture field,

$\mathrm{T}-\mathrm{V}, \mathrm{M}-\mathrm{C}=$ Variable soil texture field, constant initial soil moisture field,

$\mathrm{T}-\mathrm{V}, \mathrm{M}-\mathrm{V}=$ Variable soil texture field, variable initial soil moisture field 
Figure 9: Wind direction as a function of forecast time in 2-hr increments for 1-31 December, 2000 as observed and simulated for each region. The average within each region is over the $6 \mathrm{NWS}$ stations and over all 31 days. If observed data are missing, then results for that station and time are discarded.

$\mathrm{T}-\mathrm{C}, \mathrm{M}-\mathrm{C}=$ Constant soil texture field, constant initial soil moisture field, $\mathrm{T}-\mathrm{V}, \mathrm{M}-\mathrm{C}=$ Variable soil texture field, constant initial soil moisture field, $\mathrm{T}-\mathrm{V}, \mathrm{M}-\mathrm{V}=$ Variable soil texture field, variable initial soil moisture field

Figure 10: Wind speed as a function of forecast time in 2-hr increments for 1-29 June, 2000 as observed and simulated for each region. The average within each region is over the 6 NWS stations and over all 29 days. If observed data are missing, then results for that station and time are discarded.

$\mathrm{T}-\mathrm{C}, \mathrm{M}-\mathrm{C}=$ Constant soil texture field, constant initial soil moisture field, $\mathrm{T}-\mathrm{V}, \mathrm{M}-\mathrm{C}=$ Variable soil texture field, constant initial soil moisture field, $\mathrm{T}-\mathrm{V}, \mathrm{M}-\mathrm{V}=$ Variable soil texture field, variable initial soil moisture field

Figure 11: Wind speed as a function of forecast time in 2-hr increments for 1-31 December, 2000 as observed and simulated for each region. The average within each region is over the 6 NWS stations and over all 31 days. If observed data are missing, then results for that station and time are discarded.

$\mathrm{T}-\mathrm{C}, \mathrm{M}-\mathrm{C}=$ Constant soil texture field, constant initial soil moisture field, $\mathrm{T}-\mathrm{V}, \mathrm{M}-\mathrm{C}=$ Variable soil texture field, constant initial soil moisture field, $\mathrm{T}-\mathrm{V}, \mathrm{M}-\mathrm{V}=$ Variable soil texture field, variable initial soil moisture field

Figure 12: Temperature as a function of forecast time in 2-hr increments for 1-29 June, 2000 as observed and simulated for each region. The average within each region is over the 6 NWS stations and over all 29 days. If observed data are missing, then results for that station and time are discarded.

$\mathrm{T}-\mathrm{C}, \mathrm{M}-\mathrm{C}=$ Constant soil texture field, constant initial soil moisture field, $\mathrm{T}-\mathrm{V}, \mathrm{M}-\mathrm{C}=$ Variable soil texture field, constant initial soil moisture field,

$\mathrm{T}-\mathrm{V}, \mathrm{M}-\mathrm{V}=$ Variable soil texture field, variable initial soil moisture field

Figure 13: Temperature as a function of forecast time in 2-hr increments for 1-31 December, 2000 as observed and simulated for each region. The average within each region is over the 6 NWS stations and over all 31 days. If observed data are missing, then results for that station and time are discarded.

$\mathrm{T}-\mathrm{C}, \mathrm{M}-\mathrm{C}=$ Constant soil texture field, constant initial soil moisture field, $\mathrm{T}-\mathrm{V}, \mathrm{M}-\mathrm{C}=$ Variable soil texture field, constant initial soil moisture field,

$\mathrm{T}-\mathrm{V}, \mathrm{M}-\mathrm{V}=$ Variable soil texture field, variable initial soil moisture field

Figure 14: Dewpoint temperature as a function of forecast time in 2-hr increments for 1-29 June, 2000 as observed and simulated for each region. The average within each region is 
WSRC-TR-2001-00119

March 2001

over the 6 NWS stations and over all 29 days. If observed data are missing, then results for that station and time are discarded.

$\mathrm{T}-\mathrm{C}, \mathrm{M}-\mathrm{C}=$ Constant soil texture field, constant initial soil moisture field,

$\mathrm{T}-\mathrm{V}, \mathrm{M}-\mathrm{C}=$ Variable soil texture field, constant initial soil moisture field,

$\mathrm{T}-\mathrm{V}, \mathrm{M}-\mathrm{V}=$ Variable soil texture field, variable initial soil moisture field

Figure 15: Dewpoint temperature as a function of forecast time in 2-hr increments for 1-31

December, 2000 as observed and simulated for each region. The average within each region is over the 6 NWS stations and over all 31 days. If observed data are missing, then results for that station and time are discarded.

$\mathrm{T}-\mathrm{C}, \mathrm{M}-\mathrm{C}=$ Constant soil texture field, constant initial soil moisture field,

$\mathrm{T}-\mathrm{V}, \mathrm{M}-\mathrm{C}=$ Variable soil texture field, constant initial soil moisture field,

$\mathrm{T}-\mathrm{V}, \mathrm{M}-\mathrm{V}=$ Variable soil texture field, variable initial soil moisture field 


\section{INTRODUCTION}

Detailed knowledge of surface-characteristics such as vegetative cover, topography, and soil type are becoming increasingly important in atmospheric numerical modeling applications. Improvements in remote sensing (satellite) technology have paved the way for finer-resolution data sets of this information for larger portions of the globe. Therefore, it is now possible to perform simulations with spatially varying surface features.

The Regional Atmospheric Modeling System (RAMS, Pielke et al. 1992) is used to perform numerical atmospheric modeling simulations for a variety of applications in the Atmospheric Technologies Group (ATG), including non-proliferation, air quality, and emergency response. Current surface input features of RAMS (version 3a) include spatially variable vegetation, topography, sea-surface temperature and soil moisture. In particular, the soil moisture characterization in numerical weather prediction models is crucial to the energy transfer mechanisms at the earth's surface. The typical configuration for RAMS simulations has been to assume constant initial soil moisture in space (both horizontally and vertically) due to lack of better information. Although quantification of this variable is difficult, the National Center for Environmental Predictions (NCEP) now provides estimates of soil moisture twice daily in its large-scale numerical model products, which is based on precipitation events, wind speeds near the surface, and humidity. The soil type for a given simulation domain within RAMS has also historically been assumed to be spatially constant. Recently, a data set of global soil type at 2minute resolution (corresponding to $\sim 3 \mathrm{~km}$ in the southeastern United States) became available to ATG.

This report describes background information pertaining to both the soil type and soil moisture as they relate to the RAMS model, the techniques used to ingest this information into RAMS, as well as discussion of the impact of these changes to RAMS simulations in the southeastern United States.

\section{BACKGROUND}

\subsection{Soils}

Soils are defined to be the body of matter consisting of solids, liquid, and gases at the land surface which may or may not contain distinct horizons or layers, penetrating typically $200 \mathrm{~cm}$ below the surface (USDA 1999). In the context of atmospheric numerical modeling, the concern is with the transport of energy and mass through the earth's surface. Of particular importance is the movement of water through this porous medium. Water flow is important in determining fluxes used in numerical atmospheric models. It is determined mathematically from Darcy's Law, which expresses the relation between flux density of water (volume per area and per time) and the hydraulic gradient, or driving force behind the water movement. The proportionality constant relating these two values is the saturated hydraulic conductivity, $K_{S A T}$. It is the 
reciprocal of the resistance of the soil to water movement (i.e. as resistance increases, $K_{S A T}$ decreases).

One of the most important descriptions of a soil is its texture. The soil texture represents the relative proportions of clay, silt, and sand within a given sample. The typical diameter of these types are $<0.002 \mathrm{~mm}$ for the fine clay, 0.002 to $\sim 0.05$ for the medium silt, and $\sim 0.10$ to $2.0 \mathrm{~mm}$ for the coarse sand. The texture is important because it impacts the soil structure, porosity, permeability, water holding capacity, and cation exchange capacity (USDA 1993). For example, because the wetted surface area of the sand is much smaller than for clay, and the porosity higher, more water may flow between the individual grains. Due to generally smaller pore sizes in clay soils (compared with sandy soils), the hydraulic conductivity for clay is lower since the resistance to flow is higher (USDA 1993). A soil texture triangle (Fig. 1) may be used to describe the proportions of clay, silt and sand. Twelve major classifications are indicated with general groupings as indicated in Table 1.

Soils have been classified by a variety of institutions, most prominently by the United States Department of Agriculture (USDA 1999) and the Food and Agriculture Organization of the United Nations (FAO 1974). The data set of soil types used in this report is based on the FAO categories thus attention is focused on the latter hierarchy. The original soil mapping of the globe (FAO 1974) contains 26 major soil categories (commonly referred to as 'reference' soil groups), with subsequent revisions made in 1988. Details of the history of these changes may be found in FAO (1998). The major classifications and comments about each are given in Table 2.

The soils are defined in terms of characteristics (color, texture, structure, biological activity, void arrangement, etc.) that are observed or measured in the laboratory or field. The major categories of Table 2 are further subdivided into 106 second-level classes. The divisions are based on soil horizons (layers) roughly parallel to the earth's surface. These horizons possess a roughly uniform property over depths varying from centimeters to meters (typical depths $\sim 0.2 \mathrm{~m}$ ) and lateral ranges from one meter to several kilometers (FAO 1998).

\subsection{Soil Moisture}

Soil moisture is a very important component of the land-atmosphere exchange. Practically, it is valuable in both the agricultural and meteorological industries. Farmers require soil moisture for crop yields, while the atmospheric numerical modeling community has found soil moisture to be extremely important in generating realistic forecasts. Soil moisture is often used to "adjust" the boundary layer temperature and humidity. Physically, the soil moisture provides water vapor for precipitation through evapotranspiration and controls the splitting of net radiation into sensible and latent heat components (Famiglietti et al. 1998).

A variety of NCEP large-scale models exist that may be used as input to mesoscale models of finer horizontal and vertical spatial resolution. The Medium Range Forecast (MRF) or Aviation (AVN) model (e.g. Sela 1980) is a global spectral sigma system model providing meteorological forecasts at 12-hour intervals out to 3 days and containing a horizontal grid spacing $\sim 180 \mathrm{~km}$ at 
SRS. Soil volumetric water content is output in layers from $0-10 \mathrm{~cm}$ and $10-200 \mathrm{~cm}$ deep, following Pan and Mahrt (1987). The Eta model (Black 1994) is a step-mountain vertical coordinate model and is also available twice daily containing a horizontal grid spacing of $80 \mathrm{~km}$, but covers only North America. The Eta model land-surface scheme is discussed in Chen et al. (1997) and contains volumetric soil moisture content output at 0-10 cm, 10-40 cm, 40-100 cm and 100-200 $\mathrm{cm}$ deep. Note that mesoscale flows $(\Delta \mathrm{x} \sim 1$ to $50 \mathrm{~km})$ due to soil moisture variations at these horizontal grid spacings are not likely to occur.

\section{IMPLEMENTATION IN RAMS}

\subsection{Soil Texture}

RAMS uses 12 different soil texture classes that exhibit differences in saturated hydraulic conductivity and saturated volumetric water content (Clapp and Hornberger 1978, Cosby et al. 1984). These properties are important in the flux calculations between the earth's surface and lower atmosphere. The RAMS soil texture classes in order of increasing clay content (i.e. coarseness) are given in Table 3 (Clapp and Hornberger 1978). Note that in RAMS, the classifications for silt loam and silt (medium texture, see also Table 1) are lumped into one group, and a separate classification for highly organic materials (i.e. peat) is introduced. The key to using the FAO data set in RAMS is to relate the 133 FAO soil categories to the 12 soil texture classes. Numerous references were consulted in performing this task (USDA [1993, 1998, 1999] FAO [1974, 1988, 1998] Zobler [1986], Wilson and Henderson-Sellers [1985] and ISS [1986]). It should be stressed, however, that selection of the soil texture for each major and second-level soil type is still highly subjective.

The FAO soil types and the associated classification in RAMS from Table 3 are given in Table 4 (FAO, 1974). In Table 4, additional classifications include ocean, water, rock, and salt. The reference soil types are given in italic and a value of 0 denotes that the data do not exist within the file, or that the type is defined as water. According to this data set, the most frequent soil unit occurrence is the Lithosol soil, covering $\sim 17 \%$ of the earth's land surface. Other soil classes covering greater than $2 \%$ of the land surface include Orthic Acrisols, Orthic Ferralsols, Xanthic Ferralsols, Gelic Gleysols, Orthic Podzols, and Gelic Regosols.

After the mapping was determined, the information was placed into a special format for RAMS ingestion. The raw binary data set contains soil types at 2' resolution $(\sim 3 \mathrm{~km}$ at a latitude of $30^{\circ} \mathrm{N}$, resulting in 10800 longitudinal points and 5400 latitudinal points). The conversion for RAMS use as given in Table 4 was used to generate surface soil-type files in horizontal spatial ranges of $5^{\circ} \times 5^{\circ}$ blocks. For global coverage, this implies 2592 separate files (totaling $\sim 125$ Mbytes). The RAMS code required modifications for ingesting these files, and is discussed in the appendix.

An example of the variation in soil types is shown in Fig. 2 for the two-state region of Georgia and South Carolina currently used in operational forecasting of local conditions for the Savannah 
River Site. There is a clear demarcation in soil type from loams and sands in the land bordering the Atlantic Ocean, to more clay-rich soils further inland near the Appalachian Mountains. Note that the typical constant value of soil texture used throughout the region for simulation is sandy clay loam (category 6 from Table 3 ).

\subsection{Soil Moisture}

The soil moisture is typically set to a uniform value ( 25 to $35 \%$ by volume) throughout the domain that will increase or decrease over time and space as a result of fluxes into and out of the earth's surface during the course of the simulation. The use of spatially variable soil moisture for initial conditions is certainly more realistic than a homogenous treatment. Thus, the availability of soil moisture estimates from NCEP can be valuable. The large-scale NCEP information is available on regularly spaced latitude-longitude grids (AVN at $1^{\circ}$ with global coverage, Eta at $0.375^{\circ}$ grid spacing covering North America). It is first interpolated horizontally to the RAMS polar-stereographic grid, then vertically to the different soil levels (to a depth typically $0.5-1.0 \mathrm{~m})$.

Soil moisture is now measured in real-time at the Savannah River Site using time-domain reflectometry (TDR). The TDR method is based on dielectric property changes in the soil at microwave frequencies, and measurements must be calibrated using the gravimetric coresampling method (Robock et al. 2000). Soil moisture at SRS is measured at a depth of $\sim 15 \mathrm{~cm}$ and averages are stored every 15 minutes for two locations. One probe is within a forested area containing sandy soil, while the other probe is in a grass-covered field nearby containing additional backfill material likely consisting of clay and loam.

A comparison of observed and simulated soil moistures from the NCEP models over an extended period of time is shown in Fig. 3. Values of soil moisture from the Eta and AVN models are taken every 24 hours for the entire year 2000 in the uppermost layer of the model as interpolated to the SRS observing point. The measured soil moisture is averaged over the one-day period to correspond with the frequency of the simulated values. It is clear that the AVN model soil moisture is consistently higher than the Eta value, especially during the drier period of April, May and June. The grid size is considerably larger in the AVN model, and wetter regions to the north are probably incorporated into this average, leading to higher overall values when interpolated to the SRS. It is apparent from Fig. 3 that comparisons are more favorable in the winter months, when the spatial scale of precipitation is typically larger (i.e. less convective activity).

It is difficult to assess the results since this involves comparing spatially averaged model results (over a grid volume) with observations representing point values. However, many of the increases seen in the simulated soil moisture correspond with measured increases, indicating precipitation being accounted for in the large-scale models. The Eta model appears to be better correlated with the observations because the grid spacing is much smaller, thus more representative of the point measurements at the SRS. 


\section{APPLICATION}

A version of RAMS has been developed to provide the SRS with forecast information for daily site operations including prescribed fires conducted by the United States Forest Service and for input into emergency response transport codes (Buckley 1998). The simulation is initialized with NCEP large-scale model results. The NCEP products also provide lateral boundary conditions at 6-hr intervals beyond the initial simulation time. The current operational version utilizes variable topography and vegetation $(\sim 1 \mathrm{~km}$ resolution), as well as variable fractional land coverage and sea-surface temperatures. The soil model used in RAMS (developed by McCumber and Pielke [1981] and modified by Tremback and Kessler [1985]) is used to determine surface temperatures from surface energy balances involving net radiation, turbulent latent and sensible heat flux, and soil heat flux. The Biosphere Atmosphere Transfer Scheme (BATS, Dickinson et al. [1986]) is used for the vegetation parameterization, which further serves to modify surface fluxes.

One may assess the accuracy of the results by comparing them with measured surface observations. The variables of interest here are wind direction, wind speed, temperature, and dewpoint temperature. For these comparisons, two separate extended periods were examined, one during the warmer season with multiple precipitation events, and the other during a cooler, dryer winter period. For the summer period, 29 simulation events were generated, each beginning at 12 GMT on successive days starting June 1, 2000 and continuing for 24 hours, while for the winter time span, 31 simulations beginning December 1, 2000 were performed. Precipitation measured at the SRS (in the same location as the soil moisture probes) for each of these periods (in 24-hr increments) is indicated in Fig. 4. In addition to higher total rainfall, significant precipitation events (> 0.1 in) occur more frequently in June, especially in the latter parts of the month. The increases in soil moisture (Fig. 3) are clearly correlated with the precipitation events for each month.

For each of these time periods, three different simulations are compared with the observations. They are categorized as: (1) initially constant soil moisture (27\%) and soil type (sandy-clayloam) everywhere in the domain (i.e. texture constant T-C, moisture constant, M-C), (2) spatially variable soil type (Fig. 2) with initially constant soil moisture (T-V, M-C), and (3) spatially variable soil type and spatially variable initial soil moisture (T-V, M-V). The variable soil moisture is taken from the Eta model. Although direct comparison with observations is important, the emphasis in this report is on the inter-comparison between the 3 simulation types.

As a means of facilitating comparisons, the simulation domain is broken up into 4 separate regions, as shown in Fig. 5. Each region contains six National Weather Service (NWS) stations (see Table 5). The northwest region is denoted as "Mountain", due to the effects of the Appalachian mountain range, while the thin region bordering the Atlantic Ocean is labeled "Coastal". In addition, the mid-regions, commonly referred to geologically as piedmont, are labeled "Piedmont (GA)" and "Piedmont (SC)" depending on whether the stations are west or east of the Savannah River. It should be noted the NWS measurements are made at $2 \mathrm{~m}$ above 
ground level (AGL) for temperature and dewpoint temperature, and wind measurements are typically made at $10 \mathrm{~m}$ AGL. However, the lowest model level is $26 \mathrm{~m}$ AGL, which will necessarily lead to differences. Typically, observations at lower levels will yield lower wind speeds and temperatures, except in the event of inversions.

The initial soil moisture as interpolated to the 24 different stations from the NCEP Eta model for June and December 2000 is shown in Figs. 6 and 7, respectively. (The constant soil moisture implemented in the typical RAMS base case is also noted in each figure). It is clear that for both time periods, the greatest variability in initial soil moisture between stations in a region occurs along the coast, while the most uniform values occur in the mountainous region. The high variability along the coast may in part be due to the proximity of the stations to the ocean. In addition to simple interpolation issues with grid points located over water, increases in soil moisture may occur due to the higher evaporative demand (Entin et al. 2000). However, it is more likely the variability is influenced by regional precipitation patterns. In particular, southern Georgia and Florida were experiencing more severe drought conditions in June 2000 than northern South Carolina and North Carolina. Thus, the northern-most stations (MYR, CHS) in Fig. 6a have highest soil moisture values, while the southern-most stations (JAX, SAV) tend to be the driest. As expected, it is also evident that variability is greater during the summer period. Variability is reduced in winter conditions because radiative forcing is lower and soils are close to field capacity, implying smaller influences on surface evaporation by soil moisture (Hu et al. 1999).

Several figures have been created comparing simulated results with observations as averaged over all days in the period ( 30) and all 6 stations in each region as a function of forecast time (in 2-hr increments over the 24-hr period). If observed data for a given meteorological variable are missing, then this time period and station is not considered in the average. In this way, a statistically sufficient number of results are considered.

Comparisons of wind direction are illustrated in Figs. 8 and 9 for June and December 2000, respectively, with different sub-figures denoting the 4 regions, and each line on a figure denoting the simulation types. Similar illustrations for wind speed are given in Figs. 10 and 11. Although the addition of soil moisture and texture variations in the simulations is expected to alter temperature and humidity values, it is seen here that some influence is also exerted on the nearsurface winds. (Note that average speed and direction shown in the figures are determined by first averaging over the $u$ and $v$ horizontal wind components).

From a climatological aspect, average winds throughout the region are out of the south to southwest during the June period, typical of moisture patterns originating out of the Gulf of Mexico during this time of the year (Fig. 8), while a definite northerly trend is seen in December (Fig. 9). Speeds are highest along the coast during the summer days, while inland speeds are generally lower in the winter months (Figs. 10 and 11). It is difficult to conclude if additions of variable soil moisture/texture actually improve results relative to observations. In general, wintertime simulations are somewhat worse due to lower speeds and more variability in wind direction, especially in the Piedmont (SC) region. As for comparisons between June and 
December, adding variable initial moisture/texture effects has a more drastic impact in the summer months, due to more precipitation falling.

Similar illustrations for temperature (Figs. 12 and 13) and dewpoint (Figs. 14 and 15) show more dramatic effects. Temperature comparisons for all simulations are generally good in June (Fig. 12), with underestimates in peak temperatures at the coastal and mountainous regions, and overestimates overnight at all inland locations. Comparisons for December are worse (Fig. 13) with underestimates in daytime temperatures inland and severe overestimates at the coastal stations at night. It is apparent from Figs. 12 and 13 that the major differences between the observed and simulated values of temperature in the winter season are not due to soil moisture or soil texture variations. It is worth noting the variable soil texture leads to reductions in temperature from the base case (T-C, M-C) in all regions except Piedmont (SC). The clay content of the soils in the mountainous region (see Figs. 2 and 5) definitely results in a drop in temperature (T-V, M-C). Relative to observations, variable moisture tends to improve the simulations for all locations except Piedmont (SC) in the summer month, while improvements for the December simulations are seen at all locations except the Mountain and Piedmont (GA) regions during the day. Variable moisture effects are again more dramatic in June. Differences between constant and variable inland soil moisture (T-V, M-C and T-V, M-V) are also more dramatic during the summer, which is also not surprising given the more variable initial conditions (compare Figs. 6 and 7).

Dewpoint comparisons (Figs. 14 and 15) illustrate problems with the RAMS simulations. For the warmer period, the trend for decreasing dewpoint in the late afternoon is generally seen, but is exaggerated by RAMS in all regions (Fig. 14). Likewise, the general trend during cooler months for an increase in dewpoint after dark is simulated (Fig. 15), but in some regions, especially along the coast, dewpoint is severely overpredicted. The horizontal gradient in dewpoint (and temperature) is very high in the early winter months along the coastline, as the warmer ocean waters take longer to cool than the adjacent land surfaces. The grid spacing in RAMS is relatively coarse resulting in interpolation of warmer (wetter) water points into the coastal station results. The problem is not evident in the summer when this gradient in dewpoint is not so dramatic. As with the temperature comparisons along the coast (Fig. 13a), the gradient is more pronounced at night, leading to larger errors at this time. This logic is also supported by the fact that dewpoint comparisons for December in the Piedmont (SC) region are actually quite good.

As expected, variable moisture has the most dramatic impact on dewpoint. In opposition to the previously discussed temperature trends, dewpoint increased in all areas except the Piedmont (SC) region. In this case, the June dewpoint errors were reduced in these three regions, while increased in the Piedmont (SC) region. In December, the reverse trend is seen (Fig. 15). Again, the addition of variable soil moisture (T-V, S-V) resulted in larger changes in June, the result of more variable soil moisture conditions. Thus, there does not seem to be much correlation between the temperature and dewpoint temperature errors. 


\section{CONCLUSIONS}

An atmospheric numerical model (RAMS) requiring a variety of boundary conditions has been modified to accept spatially variable soil types and initial soil moisture. The data set of soil types is global and based on the FAO soil classification, while the RAMS model input requires soil texture. Therefore, a mapping of the FAO categories to soil texture has been performed. Comparisons between constant soil type and soil moisture simulations with cases in which one or both of these parameters is allowed to vary indicate a more dramatic impact on thermodynamic variables (surface temperature and dewpoint) than on surface winds. In addition, variability between simulation types was more pronounced during the summer period.

Improvements in simulated values relative to observations vary depending on season and location relative to the coast. Other factors such as variable initial soil moisture (T-V, M-V), as well as difficulties in comparing spatial averages with point measurements in time, make it difficult to draw definitive conclusions, even from a study such as this with 60 simulation periods and comparisons at 24 different stations. While improvements in certain regions of the simulation domain are indicated for wind direction and speed, other areas exhibit declines in performance. Therefore, a clear and significant positive impact in the overall simulation capability of RAMS using variable soil moisture and texture was not seen.

The most dramatic effect of variable soil moisture is seen near the Atlantic coast, where increased soil moisture (relative to constant values) and porous sandy soils allow for more moisture to enter the atmosphere, effectively lowering the temperatures and raising dewpoints. Soil texture changes have the most impact on the mountainous inland regions, where the originally constant sandy-clay-loam soil for the base case (T-C, M-C) is replaced with clay loam soil. The higher clay content implies a lower saturated soil hydraulic conductivity (permeability), hence, a much slower rate of water transmission through the soil, which in turn impacts near surface meteorological conditions. Changes in simulation values are more dramatic during the warmer summer period when precipitation events are more frequent. Improvements in simulated temperature are generally seen in all regions and both times of year with the inclusion of variable soil texture and initial soil moisture, with the exception of the inland stations in South Carolina during the summer period. For dewpoint, again the trends in the piedmont region of South Carolina were different for the other regions of the domain. The inclusion of variable soil moisture and texture improved the simulations during the summer month for all regions except the Piedmont (SC) area, and worsened the simulations during the winter month.

Future work in this area involves more objectively determining the mapping between the many FAO soil classes and the 12 soil texture types employed in RAMS. 


\section{REFERENCES}

Black, T. L., 1994: The New NMC mesoscale Eta model: Description and forecast examples. Wea. Forecasting, 9, 265-278.

Buckley R. L., 1998: Numerical weather forecasting at the Savannah River Site. WSRC-TR-9800210 (U), Savannah River Technology Center, Westinghouse Savannah River Company, Aiken, SC 29808, 57 pp.

Chen, F., Z. Janjic, and K. Mitchell, 1997: Impact of atmospheric surface-layer parameterizations in the new land-surface scheme of the NCEP mesoscale Eta model. Bound. Layer Meteor., 85, 391-421.

Cosby B. J., G. M. Hornberger, R. B. Clapp, and T. R. Ginn, 1984: A statistical exploration of the relationships of soil moisture characteristics to the physical properties of soils. Water Res. Research 20 (6), 682-690.

Clapp R. G. and G. M. Hornberger, 1978: Empirical equations for some soil hydraulic properties. Water Res. Research 14 (4), 601-604.

Dickinson R. E., A. Henderson-Sellers, P. J. Kennedy, and M. F. Wilson, 1986: BiosphereAtmosphere Transfer Scheme (BATS) for the NCAR Community Climate Model. National Center for Atmospheric Research, Tech. Note NCAR/TN-275+ST, 69 pp.

Entin, J. K., A. Robock, K. Y. Vinnikov, S. E. Hollinger, S. Liu, and A. Namkhai, 2000: Temporal and spatial scales of observed soil moisture variations in the extratropics. $J$. Geophys. Res., 105 (D9), 11865-11877.

Famiglietti, J. S., J. W. Rudnicki, and M. Rodell, 1998: Variability in surface moisture content along a hillslope transect: Rattlesnake Hill, Texas. J. Hydro., 210, 259-281.

FAO, 1974: Soil map of the world. Volumes 1-10. Food and Agriculture Organization of the United Nations and UNESCO, Paris. 1:5,000,000.

FAO, 1988: Soil Map of the World: Revised Legend, Food and Agriculture Organization of the United Nations, Rome. 119 pp.

FAO, 1998: World reference base for soil resources, Food and Agriculture Organization of the United Nations, Rome. Available online at http://www.fao.org/docrep/W8594E.

Hu Y., X. Gao, W. J. Shuttleworth, H. Gupta, J.-F. Mahfouf, and P. Viterbo, 1999: Soil-moisture nudging experiments with a single-column version of the ECMWF model. Q. J. R. Meteor. Soc., 125, 1879-1902. 
Institute of Soil Science (ISS), 1986: The Soil Atlas of China, Institute of Soil Science, Academia Sinica, Cartographic Publishing House, Beijing (available online at http://www.fao.org/ag/agl/swlwpnr/china/e_soils.htm).

McCumber M. C., and R. A. Pielke, 1981: Simulation of the effect of surface fluxes of heat and moisture in a mesoscale numerical model. I. Soil layer. J. Geophys. Res. 86 (C10), 99299938.

Pan, H-L. and L. Mahrt, 1987: Interaction between soil hydrology and boundary layer developments. Bound. Layer Meteor., 38, 185-202.

Robock, A., K. Y. Vinnikov, G. Srinivasan, J. K. Entin, S. E. Hollinger, N. A. Speranskaya, S. Liu, and A. Namkhai, 2000: The global soil moisture data bank. Bull. Amer. Meteor. Soc., 81 (6), 1281-1299.

Sela, J., 1980: Spectral modeling at the National Meteorological Center. Mon. Wea. Rev., 108, 1279-1292.

United States Department of Agriculture, Soil Conservation Service, 1993: Soil Survey Manual, Soil Survey Division Staff, U. S. Dept. of Agriculture Handbook 18.

United States Department of Agriculture, Natural Resources Conservation Service, 1998: Keys to Soil Taxonomy, $8^{\text {th }}$ Edition, Soil Survey Staff, 328 pp.

United States Department of Agriculture, Natural Resources Conservation Service, 1999: Soil Taxonomy: A Basic System of Soil Classification for Making and Interpreting Soil Surveys, $2^{\text {nd }}$ Edition, Soil Survey Staff, U. S. Dept. of Agriculture Handbook Number 436, 870 pp.

Tremback C. J., and R. Kessler, 1985: A surface temperature and moisture parameterization for use in mesoscale numerical models. Preprints, Seventh Conference on Numerical Weather Prediction, Montreal, Quebec, Canada, Amer. Meteor. Soc., 355-358.

Wilson M. F. and A. Henderson-Sellers, 1985: A global archive of land cover and soils data for use in general circulation climate models. J. of Climatology 5, 119-143.

Zobler L., 1986: A world soil file for global climate modeling. National Aeronautics and Space Administration, Technical memorandum 87802, 32 pp. Goddard Institute for Space Studies (GISS), 2880 Broadway, New York, NY 10025.. 
WSRC-TR-2001-00119

March 2001

Table 1: Relation of soil texture to classification

\begin{tabular}{|l|l|l|}
\hline TYPE & TEXTURE & CLASSIFICATION \\
\hline Sandy & Coarse & Sand, Loamy Sand \\
\hline & Moderately coarse & Sandy Loam \\
\hline Loamy & Medium & Loam, Silt Loam, Silt \\
\hline & Moderately fine & Clay Loam, Sandy Clay Loam, Silty Clay Loam \\
\hline Clayey & Fine & Sandy Clay, Silty Clay, Clay \\
\hline
\end{tabular}


Table 2: FAO (1974) Major Soil Categories

\begin{tabular}{|l|l|}
\hline Reference Group & \\
\hline Acrisols & Acidic soils with clay layer \\
\hline Andosols & Dark soils formed from volcanic materials \\
\hline Arensols & Sandy soil \\
\hline Cambisols & Light-colored soil with slight profile development \\
\hline Chernozems & Dark soils, rich in organic matter \\
\hline Ferralsols & Weathered soils containing much clay and low cation exchange \\
\hline Fluvisols & Flood plain (alluvial) soils \\
\hline Gleysols & Hydromorphic (water saturated) soils that are not salty \\
\hline Greyzems & Dark soils, rich in organic matter, bleached coatings \\
\hline Histosols & Highly organic soils (>14\%) \\
\hline Kastanozems & Darks soils, rich in organic matter \\
\hline Lithosols & Very shallow soils existing over hard rock \\
\hline Luvisols & Light-colored soils with strong clay layer \\
\hline Nitosols & Acidic soils with very thick clay layer \\
\hline Phaeozems & Darks soils, rich in organic matter \\
\hline Planosols & Highly impermeable soil \\
\hline Podzols & Strongly bleached layered soil containing iron or aluminum \\
\hline Podzoluvisols & Bleached layered soil with strong iron content \\
\hline Rankers & Shallow, richly organic dark soils formed from siliceous material \\
\hline Regosols & Rocky materials at the surface \\
\hline Rendzinas & Dark, richly organic soils formed from calcareous materials \\
\hline Solonchaks & Soils high in salinity \\
\hline Solonetz & Salty soil, high concentration of sodium \\
\hline Vertisols & High clay content \\
\hline Xerosols & Aridic (dry) soils \\
\hline Yermosols & Aridic (dry) soils \\
\hline
\end{tabular}


WSRC-TR-2001-00119

March 2001

Table 3: Soil texture classification used in RAMS, version 3a.

\begin{tabular}{|ll||ll|}
\hline & Soil Texture & & Soil Texture \\
\hline $\mathbf{1}$ & Sand & $\mathbf{7}$ & Silty Clay Loam \\
$\mathbf{2}$ & Loamy Sand & $\mathbf{8}$ & Clay Loam \\
$\mathbf{3}$ & Sandy Loam & $\mathbf{9}$ & Sandy Clay \\
$\mathbf{4}$ & Silt Loam & $\mathbf{1 0}$ & Silty Clay \\
$\mathbf{5}$ & Loam & $\mathbf{1 1}$ & Clay \\
$\mathbf{6}$ & Sandy Clay Loam & $\mathbf{1 2}$ & Peat \\
\hline
\end{tabular}


Table 4: Conversion factor between FAO type and soil texture

\begin{tabular}{|c|c|c|c|c|c|}
\hline FAO Type & ST & FAO Type & ST & FAO Type & ST \\
\hline Ocean & 0 & Haplic Phaeozem & 4 & Calcaric Regosol & 5 \\
\hline Acrisols & 0 & Luvic Phaeozem & 5 & Dystric Regosol & 2 \\
\hline Ferric Acrisol & 5 & Lithosols & 4 & Eutric Regosol & $\mathbf{1}$ \\
\hline Gleyic Acrisol & 5 & Fluvisols & 4 & Gelic Regosol & 2 \\
\hline Humic Acrisol & 8 & Calcaric Fluvisol & 4 & Solonetz & 5 \\
\hline Orthic Acrisol & 8 & Dystric Fluvisol & 4 & Gleyic Solonetz & 2 \\
\hline Plinthic Acrisol & 6 & Eutric Fluvisol & 4 & Mollic Solonetz & 5 \\
\hline Cambisols & 0 & Thionic Fluvisol & 4 & Orthic Solonetz & 3 \\
\hline Chromic Cambisol & 4 & Kastanozems & 4 & Andosols & 0 \\
\hline Dystric Cambisol & 4 & Haplic Kastanozem & 4 & Humic Andosol & 12 \\
\hline Eutric Cambisol & 4 & Calcic Kastanozem & 5 & Mollic Andosol & 8 \\
\hline Ferralic Cambisol & 8 & Luvic Kastanozem & 4 & Ochric Andosol & 8 \\
\hline Gleyic Cambisol & 4 & Luvisols & 2 & Vitric Andosol & 8 \\
\hline Humic Cambisol & 5 & Albic Luvisol & 4 & Rankers & 4 \\
\hline Calcic Cambisol & 4 & Chromic Luvisol & 5 & Vertisols & 10 \\
\hline Vertic Cambisol & 10 & Ferric Luvisol & 2 & Chromic Vertisol & 10 \\
\hline Gelic Cambisol & 4 & Gleyic Luvisol & 8 & Pellic Vertisol & 7 \\
\hline Chernozems & 10 & Calcic Luvisol & 3 & Planasols & 3 \\
\hline Glossic Chernozems & 4 & Orthic Luvisol & 5 & Dystric Planasol & 8 \\
\hline Halpic Chernozems & 4 & Plinthic Luvisol & 2 & Eutric Planasol & 5 \\
\hline Calcic Chernozem & 4 & Vertic Luvisol & 8 & Humic Planasol & 4 \\
\hline Luvic Chernozem & 4 & Greyzems & 0 & Mollic Planasol & 4 \\
\hline Podzoluvisols & 2 & Gleyic Greyzem & 12 & Solodic Planasol & 3 \\
\hline Dystric Podzoluvisol & 3 & Orthic Greyzem & 12 & Gelic Planasol & $\mathbf{0}$ \\
\hline Eutric Podzoluvisol & 4 & Nitosols & $\mathbf{0}$ & Xerosols & 5 \\
\hline Gleyic Podzoluvisol & 4 & Dystric Nitosol & 7 & Halpic Xerosol & 1 \\
\hline Rendzinas & 5 & Eutric Nitosol & 7 & Calcic Xerosol & 5 \\
\hline Ferralsols & 0 & Humic Nitosol & 8 & Luvic Xerosol & 5 \\
\hline Acric Ferralsol & 11 & Histosols & 2 & Gypsic Xerosol & 3 \\
\hline Humic Ferralsol & 11 & Dystric Histosol & 12 & Yermosols & 2 \\
\hline Orthic Ferralsol & 11 & Eutric Histosol & 12 & Halpic Yermosol & 2 \\
\hline Plinthic Ferralsol & 4 & Gelic Histosol & 12 & Calcic Yermosol & 2 \\
\hline Phodic Ferralsol & 11 & Podzols & 0 & Luvic Yermosol & 5 \\
\hline Xanthic Ferralsol & 11 & Ferric Podzol & $\mathbf{0}$ & Takyric Yermosol & 6 \\
\hline Gleysols & 2 & Gleyic Podzol & 5 & Gypsic Yermosol & $\mathbf{1}$ \\
\hline Calcaric Gleysol & 6 & Humic Podzol & 5 & Solonchaks & 4 \\
\hline Dystric Gleysol & 4 & Leptic Podzol & 5 & Gleyic Solonchak & 8 \\
\hline Eutric Gleysol & 8 & Orhic Podzol & 5 & Mollic Solonchak & 8 \\
\hline Humic Gleysol & 5 & Plasic Podzol & 5 & Orthic Solonchak & 9 \\
\hline Mollic Gleysol & 4 & Arenosols & 0 & Takyric Solonchak & 3 \\
\hline Plinthic Gleysol & 3 & Albic Arenosol & 1 & Rock & 1 \\
\hline Gelic Gleysol & 4 & Cambic Arenosol & 2 & Salt & 1 \\
\hline Phaeozems & 0 & Ferralic Arenosol & 1 & Water & $\mathbf{0}$ \\
\hline Calcaric Phaeozem & 11 & Luvic Arenosol & 1 & No name (water) & $\mathbf{0}$ \\
\hline Gleyic Phaeozem & 4 & Regosols & 1 & & \\
\hline
\end{tabular}


WSRC-TR-2001-00119

March 2001

Table 5: Location of National Weather Service stations used in the modeling comparisons

\begin{tabular}{|c|c|c|c|c|c|}
\hline Region & $\begin{array}{c}\text { Station } \\
I D\end{array}$ & Location & $\begin{array}{c}\text { Longitude } \\
\left({ }^{\circ} \mathrm{E}\right)\end{array}$ & $\begin{array}{c}\text { Latitude } \\
\left({ }^{\circ} \mathrm{N}\right)\end{array}$ & $\begin{array}{l}\text { Elevation } \\
(m A S L) *\end{array}$ \\
\hline & SAV & Savannah, GA & -81.20 & 32.12 & 14 \\
\hline & SSI & Brunswick, GA & -81.38 & 31.15 & 6 \\
\hline \multirow[t]{6}{*}{ Coastal } & $\mathrm{CHS}$ & Charleston, SC & -80.03 & 32.90 & 13 \\
\hline & MYR & Myrtle Beach, SC & -78.93 & 33.68 & 8 \\
\hline & $\mathrm{NBC}$ & Beaufort, SC & -80.72 & 32.48 & 8 \\
\hline & JAX & Jacksonville, FL & -81.70 & 30.50 & 7 \\
\hline & AHN & Athens, GA & -83.32 & 33.95 & 244 \\
\hline & ATL & Atlanta, GA & -84.42 & 33.65 & 296 \\
\hline \multirow{6}{*}{ Mountainous } & AND & Anderson, SC & -82.72 & 34.50 & 239 \\
\hline & GSP & Greenville, SC & -82.22 & 34.88 & 286 \\
\hline & AVL & Asheville, NC & -82.55 & 35.43 & 670 \\
\hline & CLT & Charlotte, $\mathrm{NC}$ & -80.93 & 35.22 & 220 \\
\hline & ABY & Albany, GA & -84.18 & 31.53 & 58 \\
\hline & AGS & Augusta, GA (Bush) & -81.97 & 33.37 & 44 \\
\hline \multirow[t]{6}{*}{ Piedmont (GA) } & AMG & Alma, GA & -82.50 & 31.53 & 59 \\
\hline & VLD & Valdosta, GA & -83.28 & 30.78 & 62 \\
\hline & WRB & Warner-Robbins, GA & -83.60 & 32.63 & 90 \\
\hline & DNL & Augusta, GA (Daniel) & -82.00 & 33.40 & 130 \\
\hline & $\mathrm{CAE}$ & Columbia, SC (Metro) & -81.12 & 33.95 & 73 \\
\hline & FLO & Florence, SC & -79.72 & 34.18 & 44 \\
\hline \multirow[t]{4}{*}{ Piedmont (SC) } & SSC & Sumter, SC & -80.47 & 33.97 & 73 \\
\hline & FAY & Fayetteville, NC & -78.88 & 34.98 & 55 \\
\hline & CUB & Columbia, SC (Owen) & -81.00 & 33.97 & 56 \\
\hline & OGB & Orangeburg, SC & -80.86 & 33.46 & 59 \\
\hline
\end{tabular}

*(meters above sea level) 


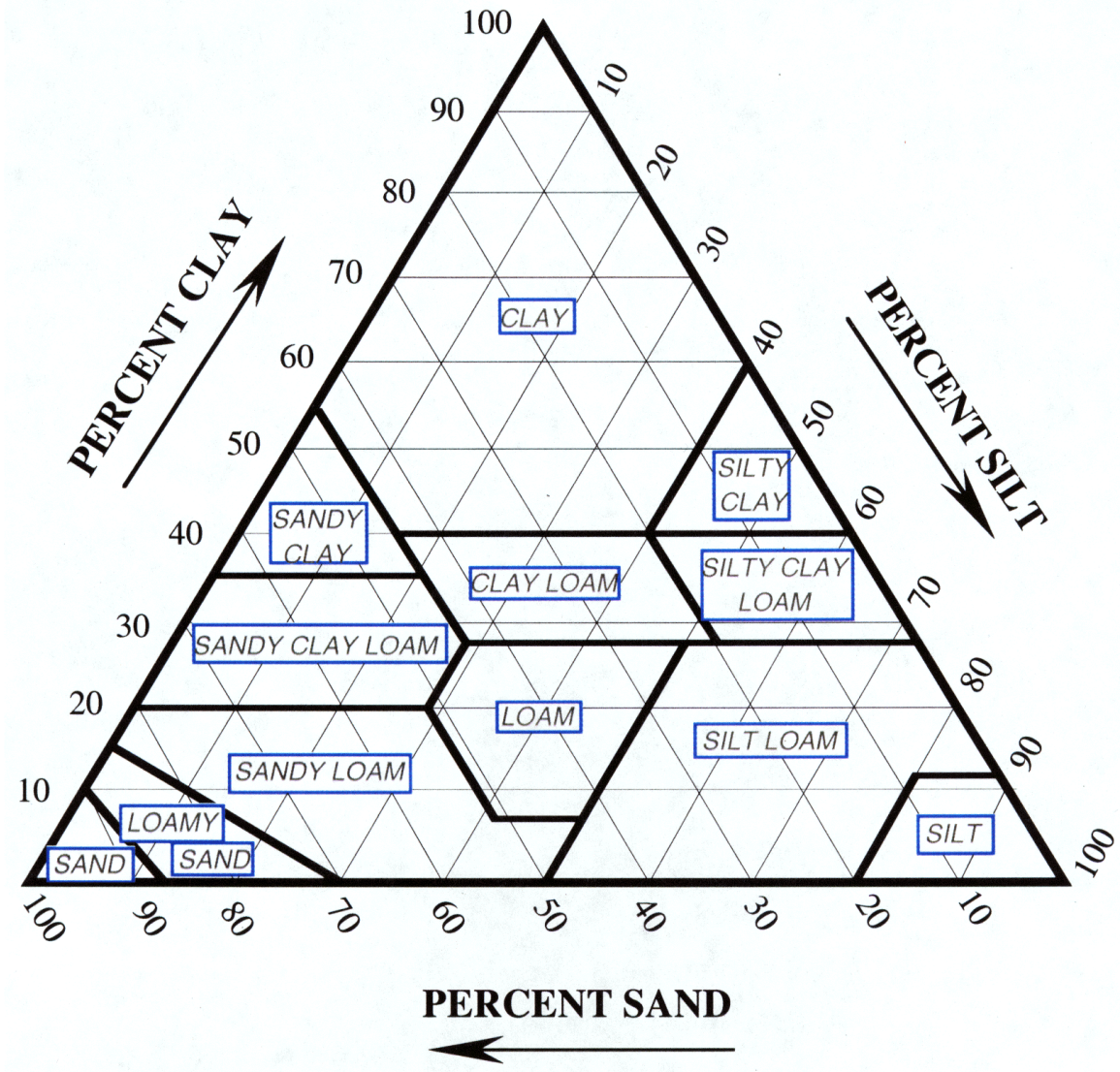

Figure 1: Soil texture triangle showing the mass content of clay, silt and sand for the different soil texture types (adapted from USDA 1998). 
WSRC-TR-2001-00119

March 2001

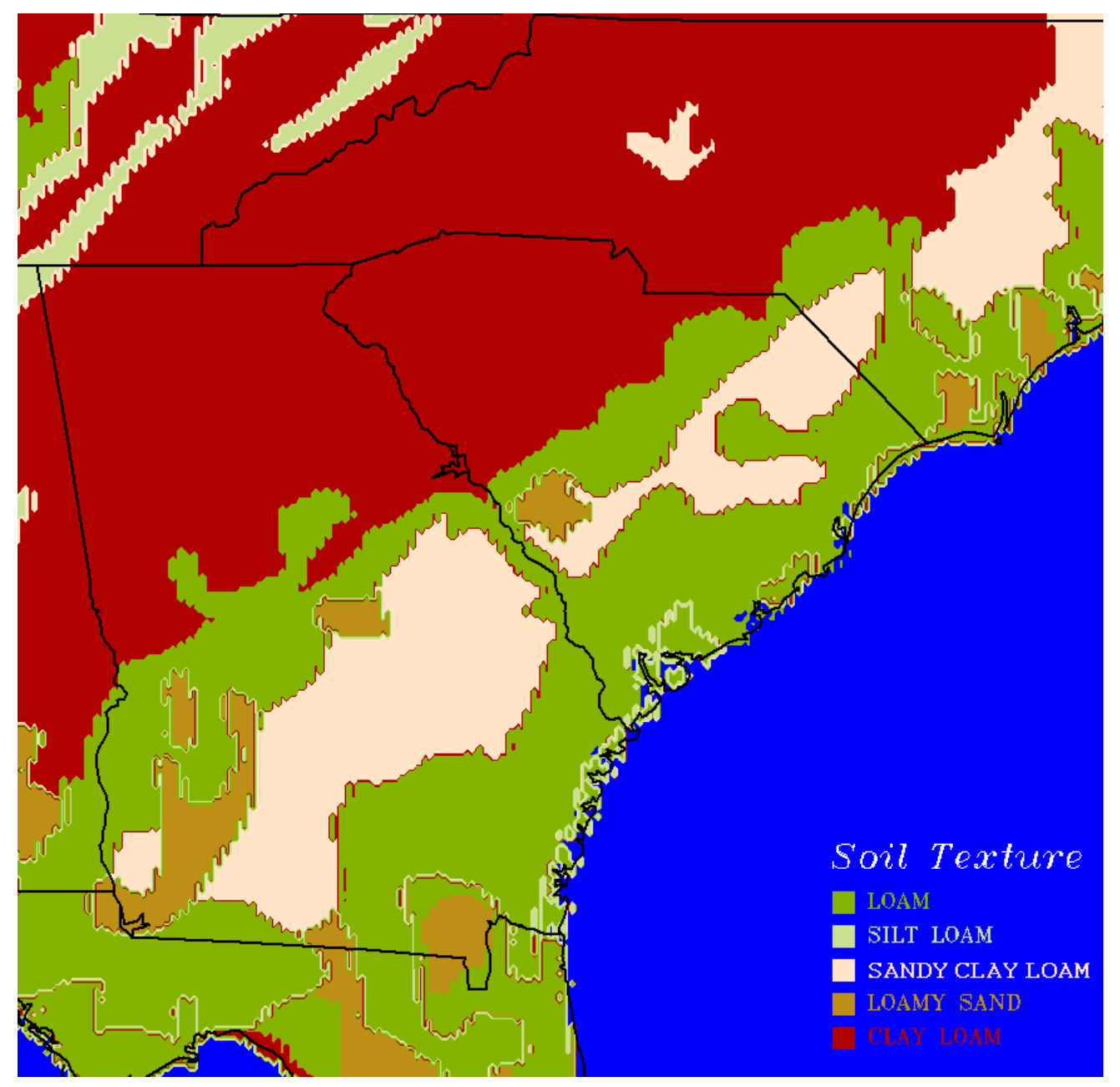

Figure 2: Soil texture for the southeast United States using the mapping procedure. 
WSRC-TR-2001-00119

March 2001

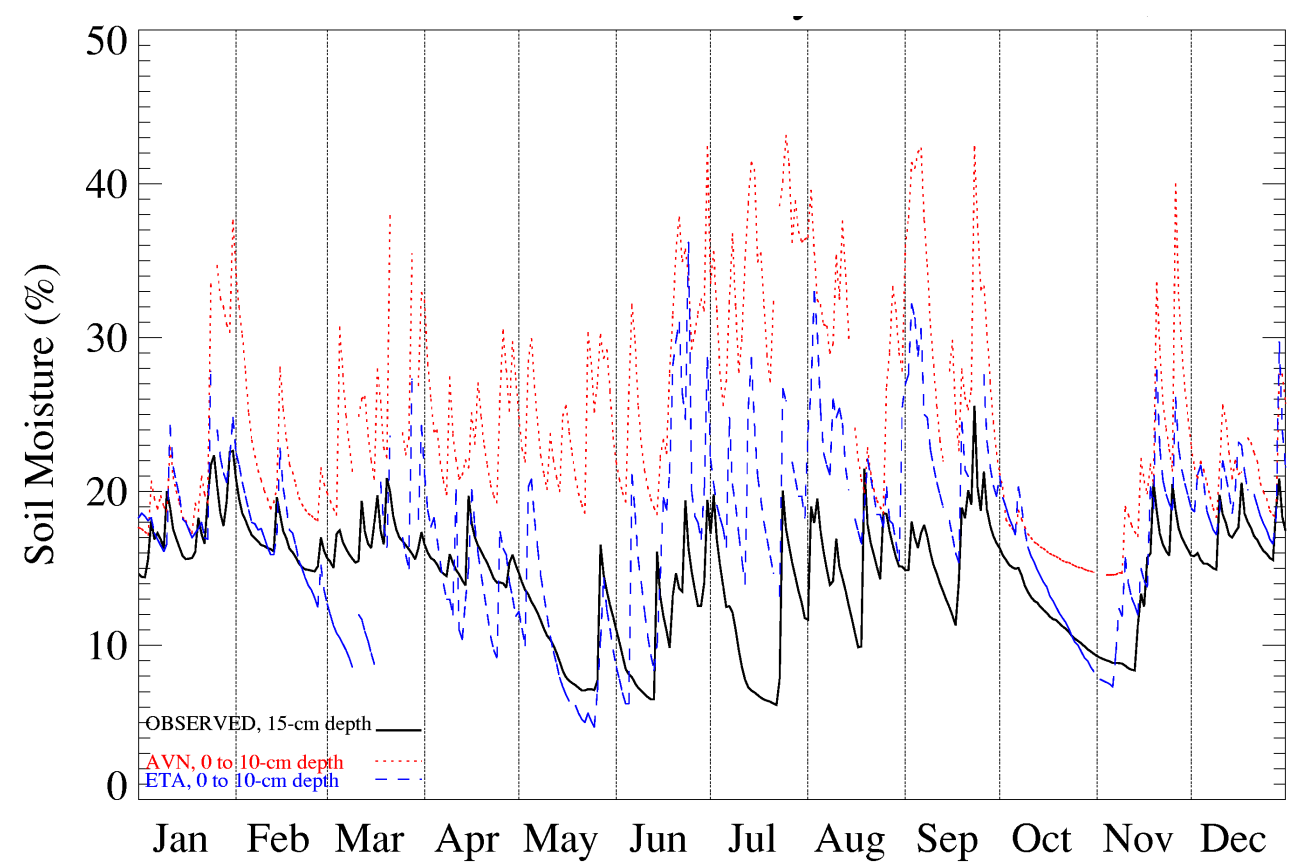

Figure 3: Comparison of observed soil moisture [\%] and large-scale NCEP AVN and Eta numerical models at 24-hr increments over a one year period beginning 1 January 2000 . 


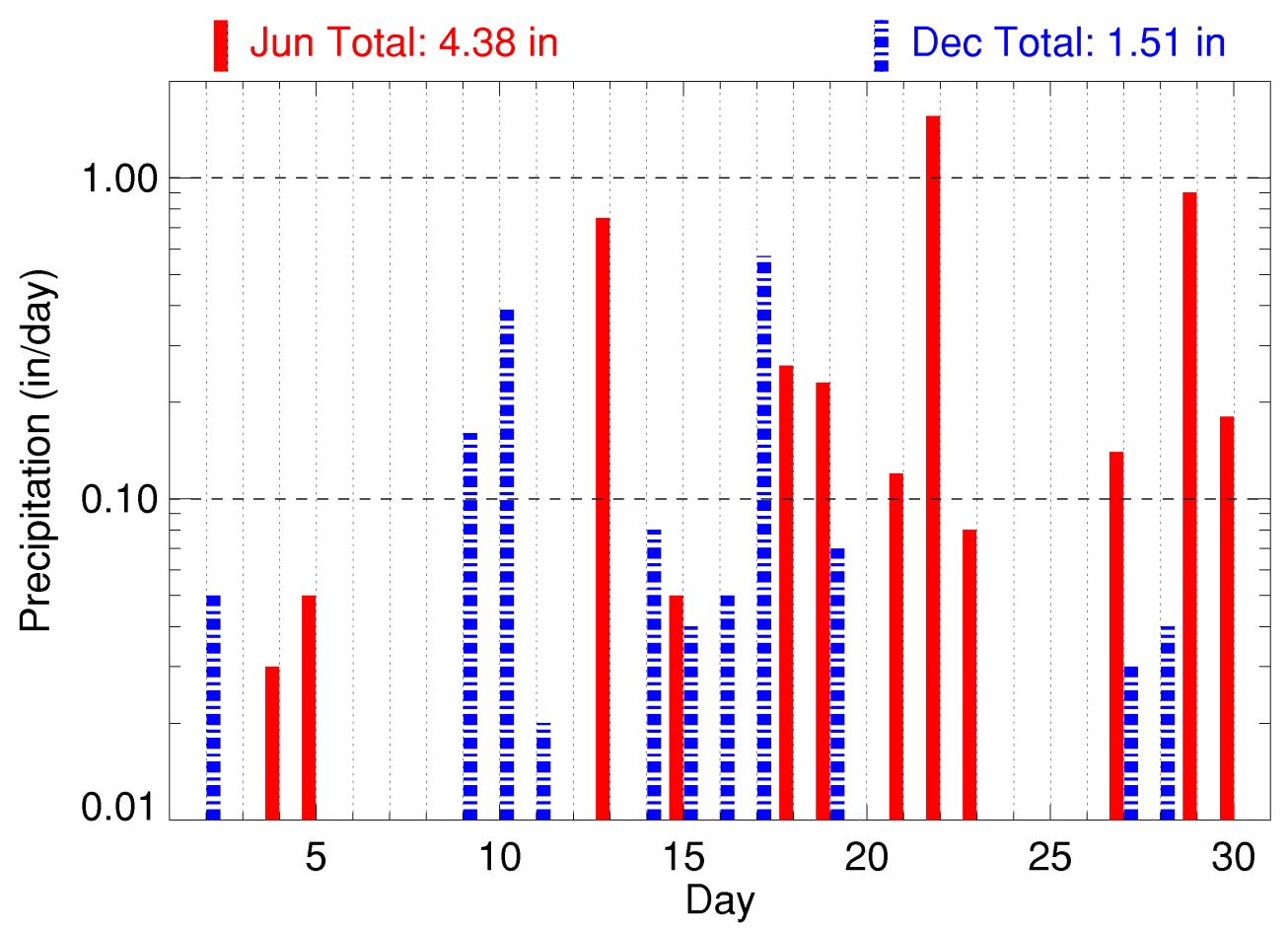

Figure 4: Measured precipitation from the SRS (using a tipping-bucket rain gauge co-located with the soil-moisture probe) during the months of June and December 2000 as totaled over a 24 -hr period. Note that the precipitation scale is logarithmic, and the total precipitation for each month is indicated at the top of the figure. 


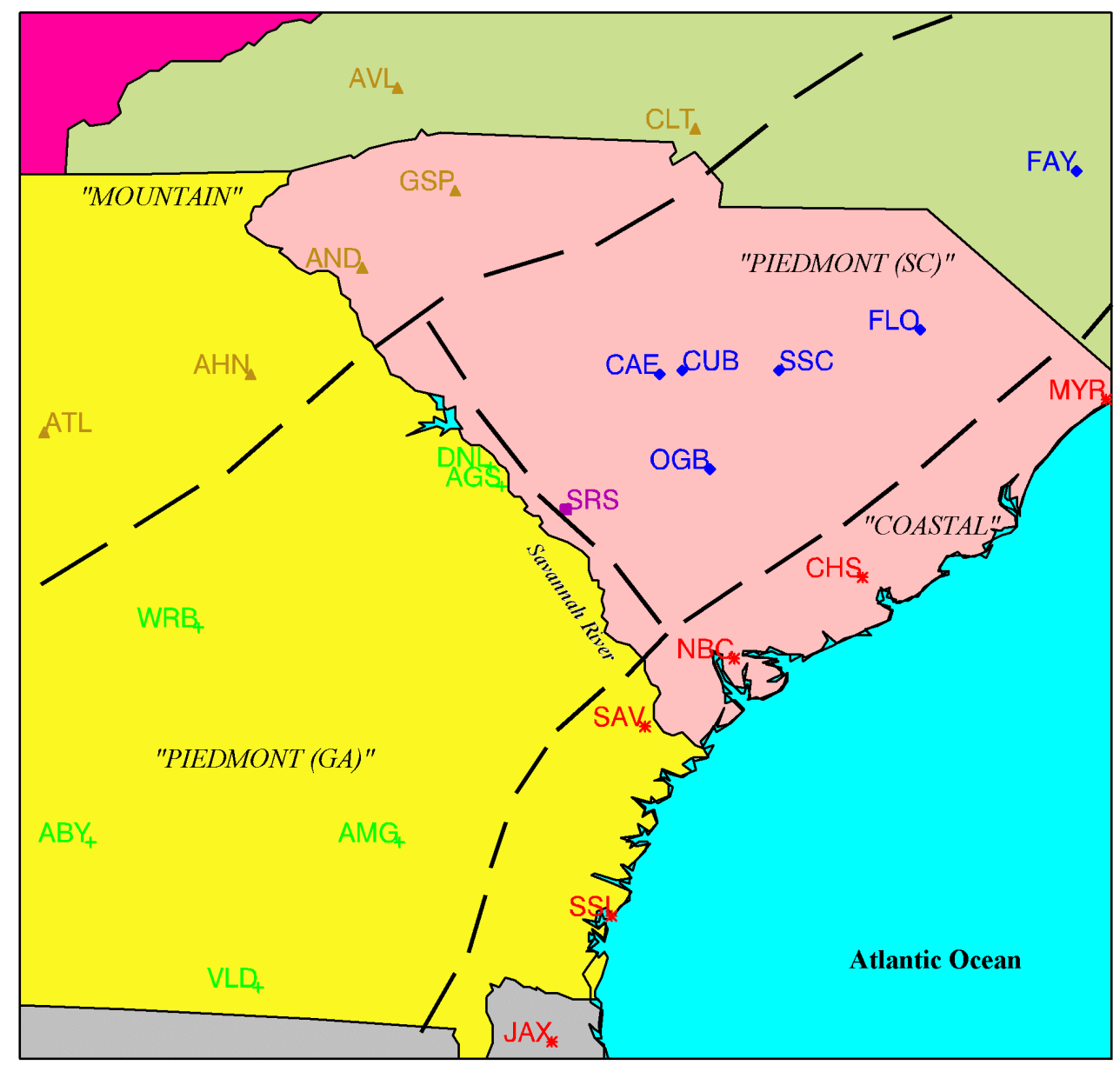

Figure 5: Location of stations within the simulation domain and the labeling of different regions. There are 6 NWS stations labeled within each region. See Table 5 for a description of each location. 
WSRC-TR-2001-00119

March 2001
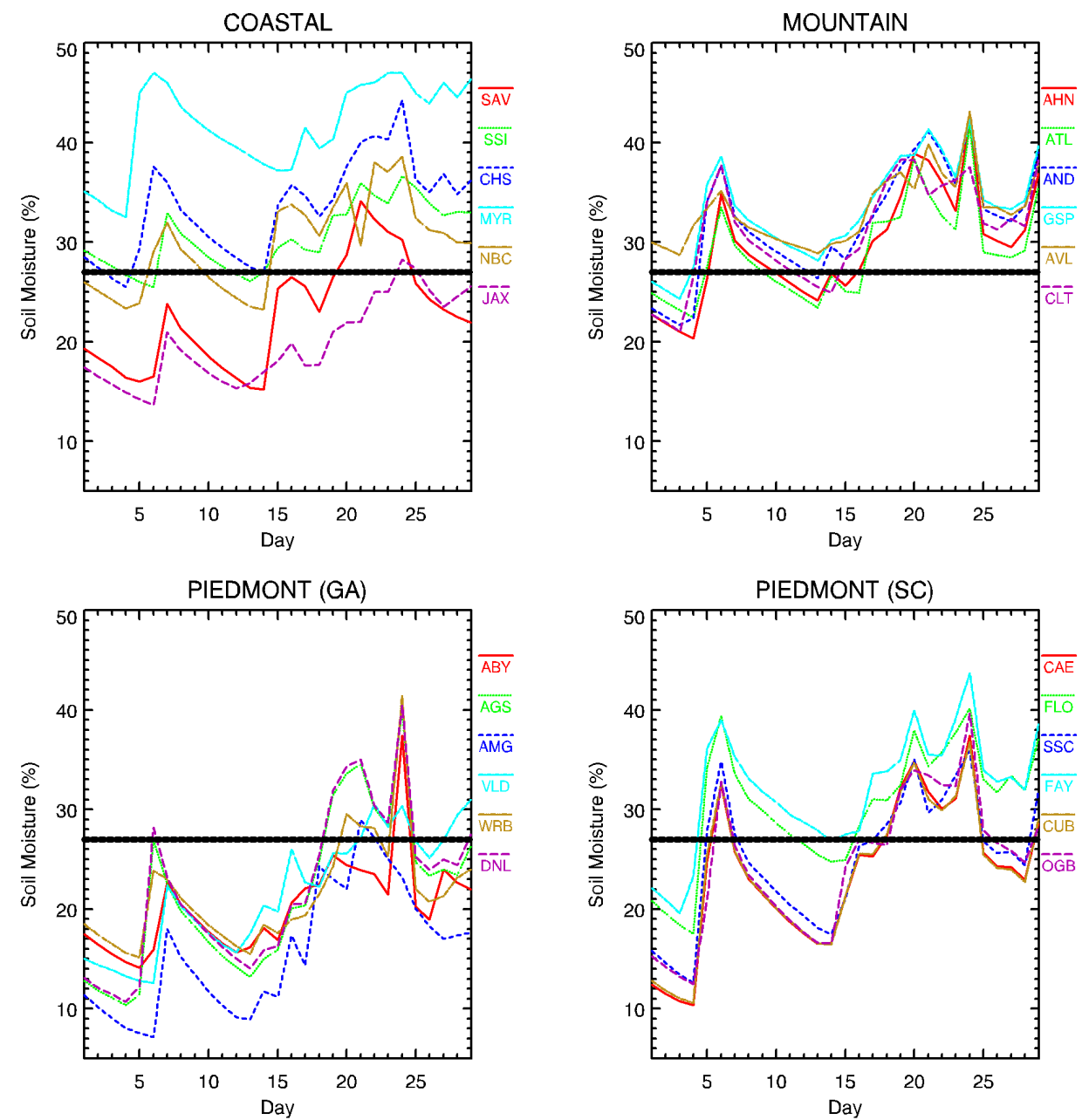

Figure 6: Eta-derived soil moisture for the period 1-29 June, 2000 as interpolated to the 6 NWS station locations for each region as labeled in Fig. 5. 
WSRC-TR-2001-00119

March 2001
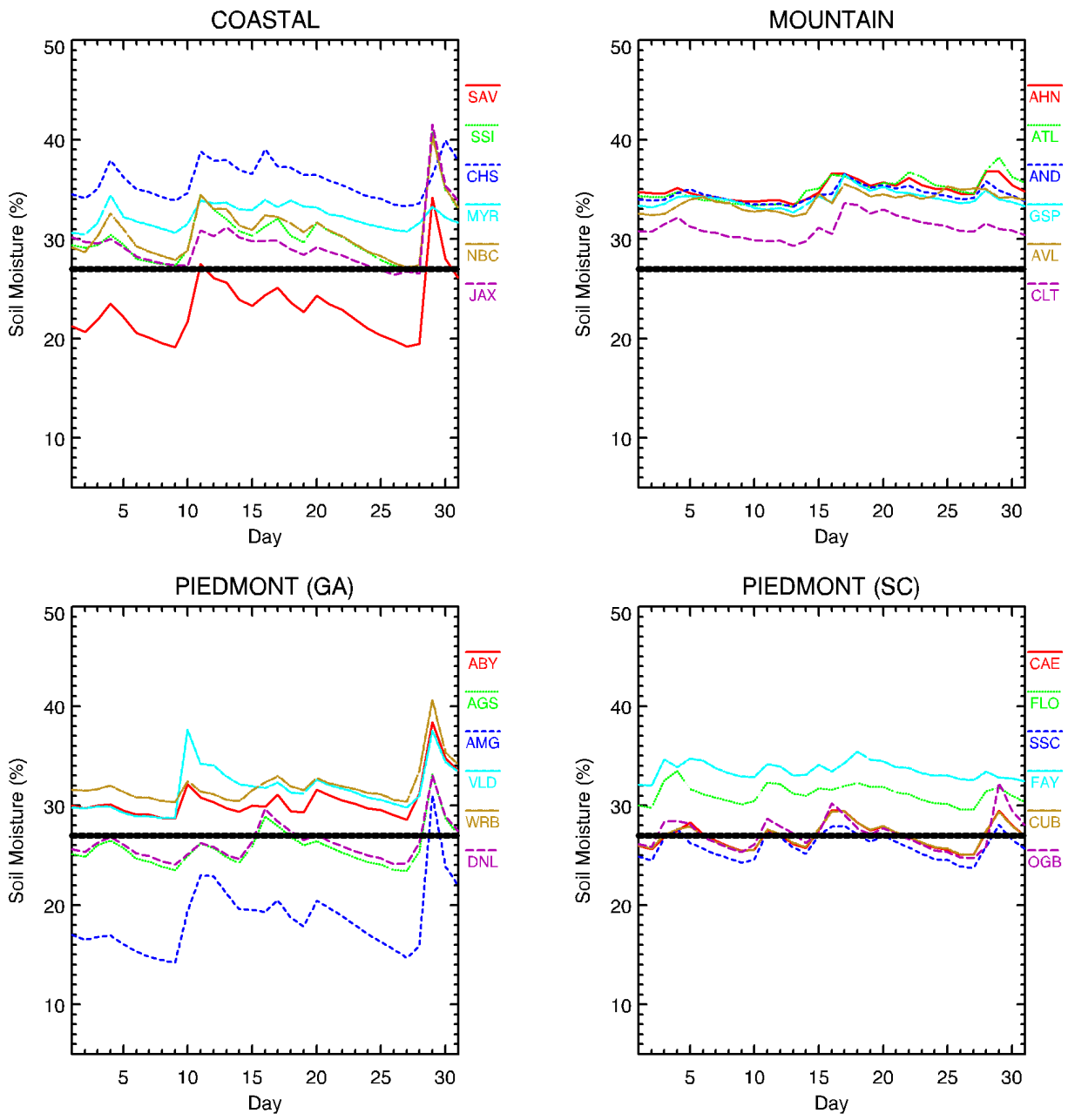

Figure 7: Eta-derived soil moisture for the period 1-31 December, 2000 as interpolated to the 6 NWS station locations for each region as labeled in Fig. 5. 

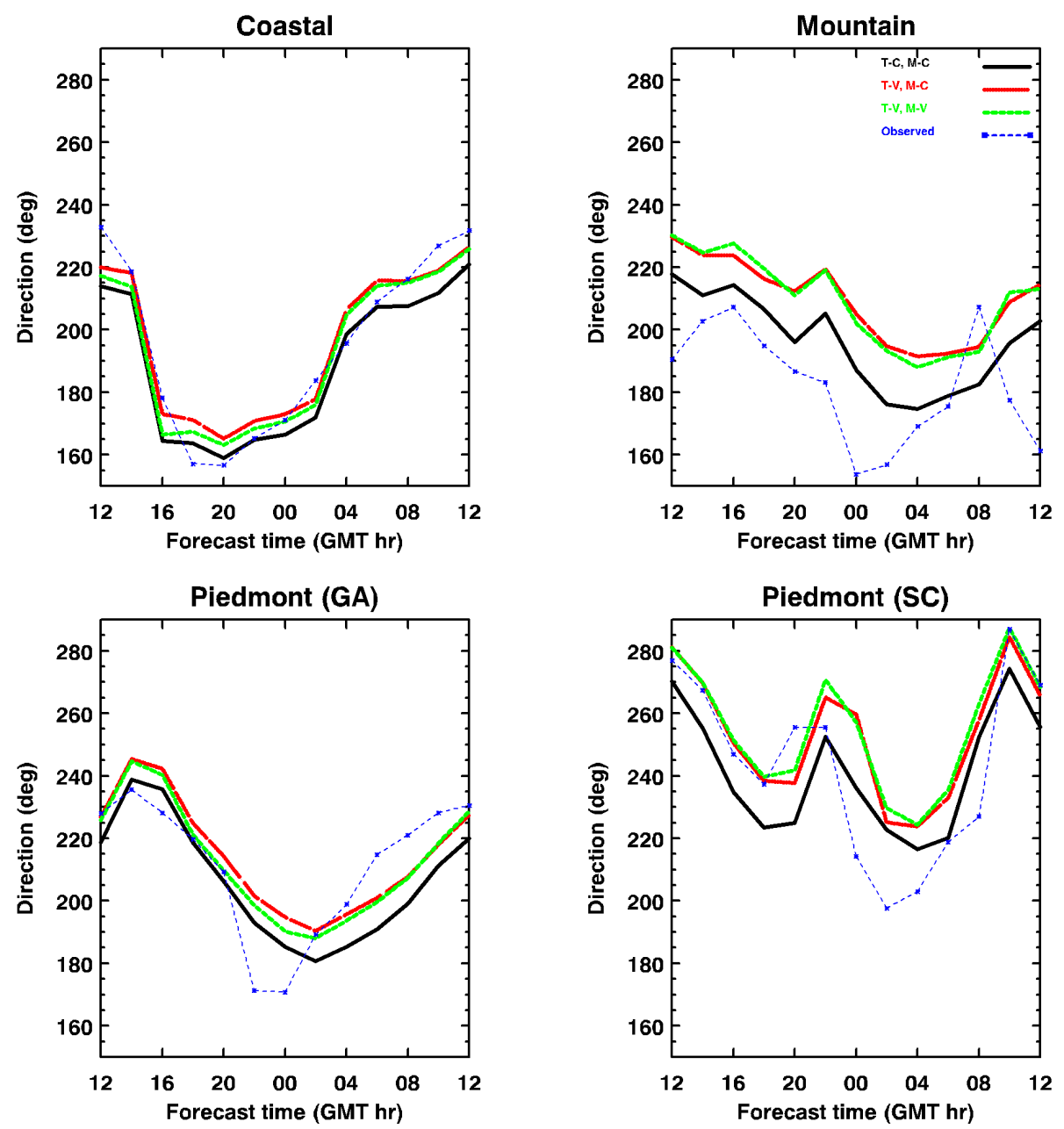

Figure 8: Wind direction as a function of forecast time in 2-hr increments for 1-29 June, 2000 as observed and simulated for each region. The average within each region is over the 6 NWS stations and over all 29 days. If observed data are missing, then results for that station and time are discarded.

$\mathrm{T}-\mathrm{C}, \mathrm{M}-\mathrm{C}=$ Constant soil texture field, constant initial soil moisture field,

$\mathrm{T}-\mathrm{V}, \mathrm{M}-\mathrm{C}=$ Variable soil texture field, constant initial soil moisture field,

$\mathrm{T}-\mathrm{V}, \mathrm{M}-\mathrm{V}=$ Variable soil texture field, variable initial soil moisture field 

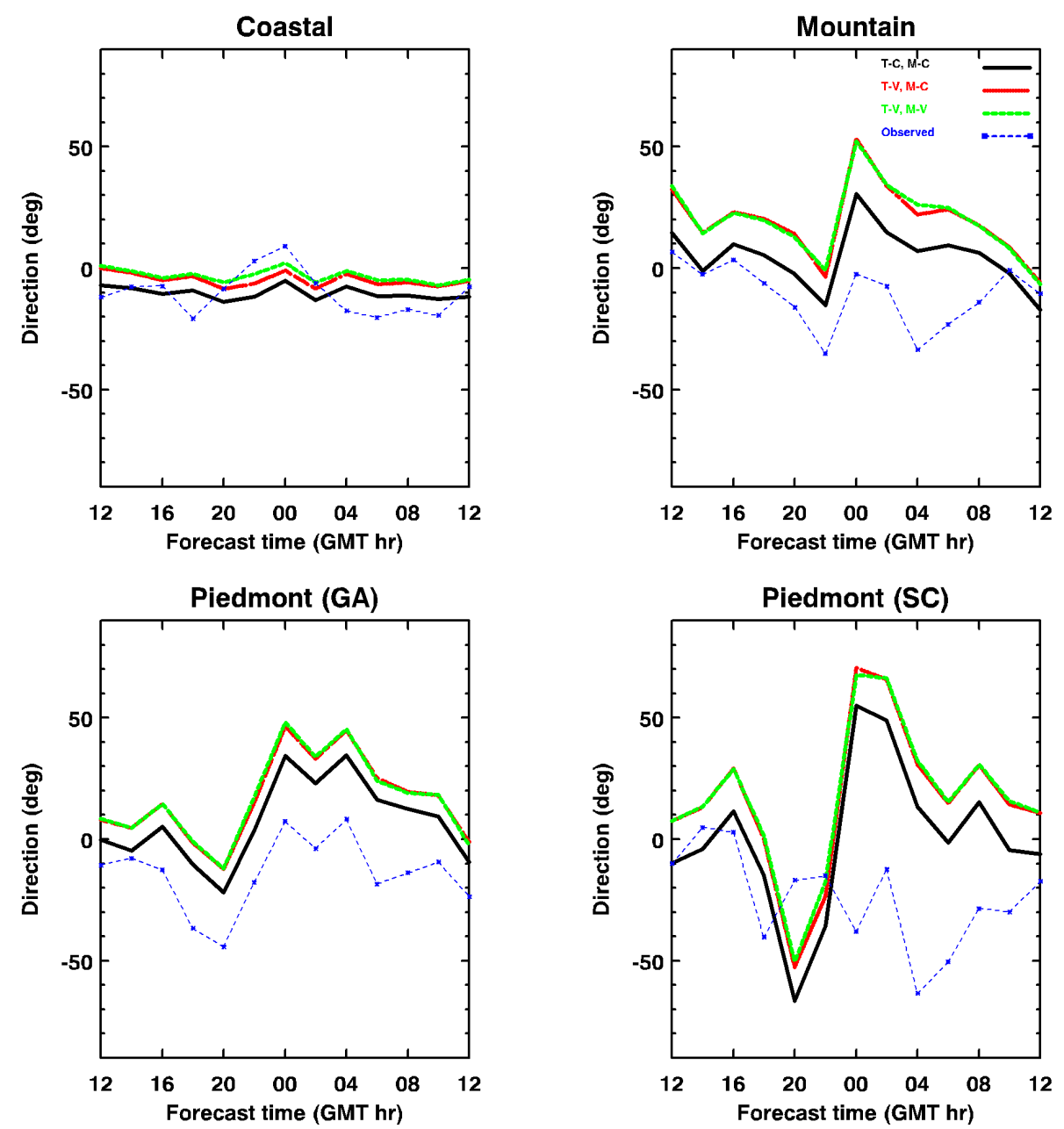

Figure 9: Wind direction as a function of forecast time in 2-hr increments for 1-31 December, 2000 as observed and simulated for each region. The average within each region is over the 6 NWS stations and over all 31 days. If observed data are missing, then results for that station and time are discarded.

T-C, M-C $=$ Constant soil texture field, constant initial soil moisture field,

$\mathrm{T}-\mathrm{V}, \mathrm{M}-\mathrm{C}=$ Variable soil texture field, constant initial soil moisture field,

$\mathrm{T}-\mathrm{V}, \mathrm{M}-\mathrm{V}=$ Variable soil texture field, variable initial soil moisture field 



Figure 10: Wind speed as a function of forecast time in 2-hr increments for 1-29 June, 2000 as observed and simulated for each region. The average within each region is over the 6 NWS stations and over all 29 days. If observed data are missing, then results for that station and time are discarded.

$\mathrm{T}-\mathrm{C}, \mathrm{M}-\mathrm{C}=$ Constant soil texture field, constant initial soil moisture field,

$\mathrm{T}-\mathrm{V}, \mathrm{M}-\mathrm{C}=$ Variable soil texture field, constant initial soil moisture field,

$\mathrm{T}-\mathrm{V}, \mathrm{M}-\mathrm{V}=$ Variable soil texture field, variable initial soil moisture field 

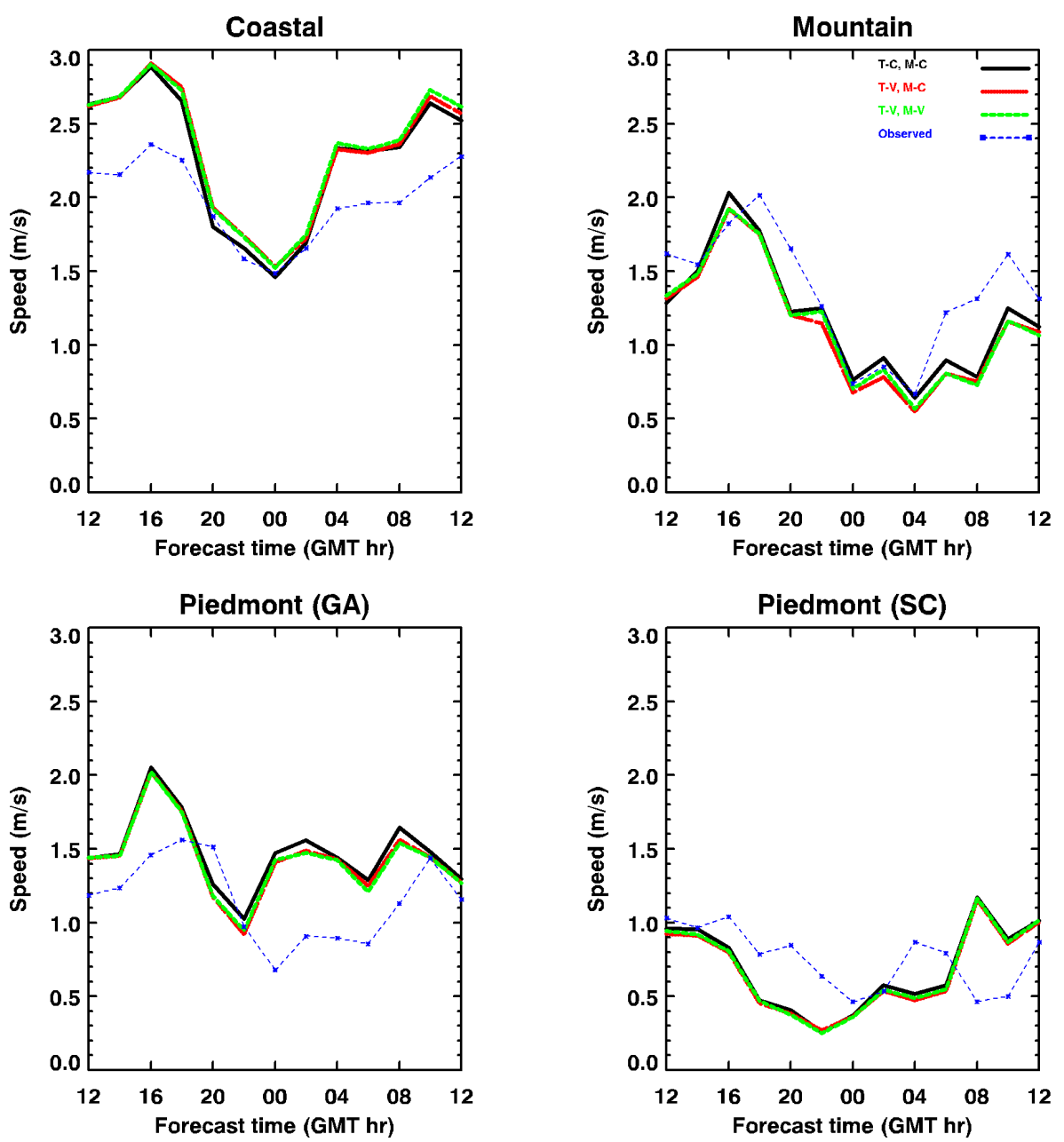

Figure 11: Wind speed as a function of forecast time in 2-hr increments for 1-31 December, 2000 as observed and simulated for each region. The average within each region is over the 6 NWS stations and over all 31 days. If observed data are missing, then results for that station and time are discarded.

$\mathrm{T}-\mathrm{C}, \mathrm{M}-\mathrm{C}=$ Constant soil texture field, constant initial soil moisture field,

$\mathrm{T}-\mathrm{V}, \mathrm{M}-\mathrm{C}=$ Variable soil texture field, constant initial soil moisture field,

$\mathrm{T}-\mathrm{V}, \mathrm{M}-\mathrm{V}=$ Variable soil texture field, variable initial soil moisture field 



Figure 12: Temperature as a function of forecast time in 2-hr increments for 1-29 June, 2000 as observed and simulated for each region. The average within each region is over the 6 NWS stations and over all 29 days. If observed data are missing, then results for that station and time are discarded.

$\mathrm{T}-\mathrm{C}, \mathrm{M}-\mathrm{C}=$ Constant soil texture field, constant initial soil moisture field,

$\mathrm{T}-\mathrm{V}, \mathrm{M}-\mathrm{C}=$ Variable soil texture field, constant initial soil moisture field,

$\mathrm{T}-\mathrm{V}, \mathrm{M}-\mathrm{V}=$ Variable soil texture field, variable initial soil moisture field 
WSRC-TR-2001-00119
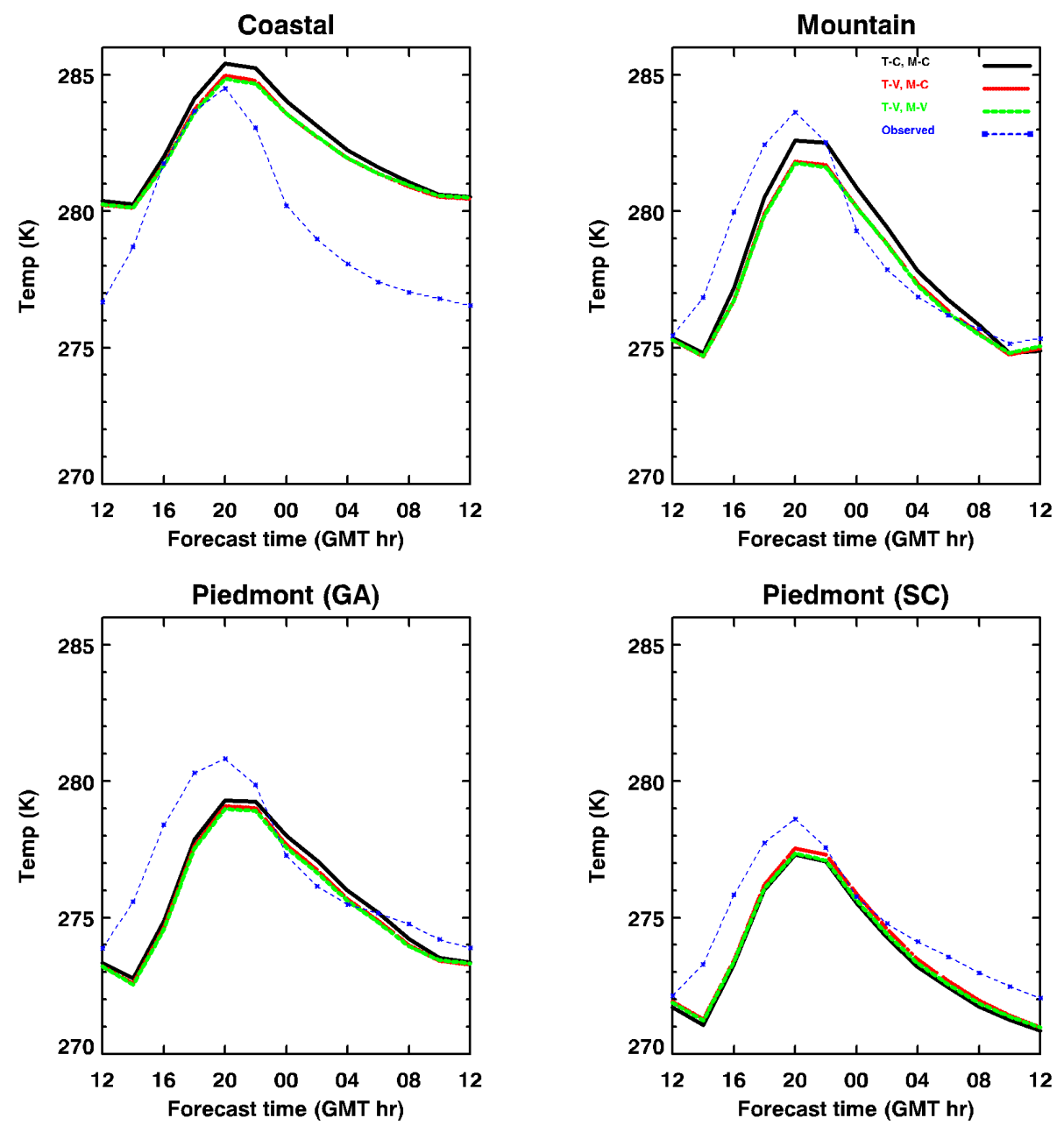

Figure 13: Temperature as a function of forecast time in 2-hr increments for 1-31 December, 2000 as observed and simulated for each region. The average within each region is over the 6 NWS stations and over all 31 days. If observed data are missing, then results for that station and time are discarded.

$\mathrm{T}-\mathrm{C}, \mathrm{M}-\mathrm{C}=$ Constant soil texture field, constant initial soil moisture field,

$\mathrm{T}-\mathrm{V}, \mathrm{M}-\mathrm{C}=$ Variable soil texture field, constant initial soil moisture field,

$\mathrm{T}-\mathrm{V}, \mathrm{M}-\mathrm{V}=$ Variable soil texture field, variable initial soil moisture field 
WSRC-TR-2001-00119


Figure 14: Dewpoint temperature as a function of forecast time in 2-hr increments for 1-29 June, 2000 as observed and simulated for each region. The average within each region is over the 6 NWS stations and over all 29 days. If observed data are missing, then results for that station and time are discarded.

T-C, M-C $=$ Constant soil texture field, constant initial soil moisture field,

$\mathrm{T}-\mathrm{V}, \mathrm{M}-\mathrm{C}=$ Variable soil texture field, constant initial soil moisture field,

$\mathrm{T}-\mathrm{V}, \mathrm{M}-\mathrm{V}=$ Variable soil texture field, variable initial soil moisture field 
WSRC-TR-2001-00119

March 2001
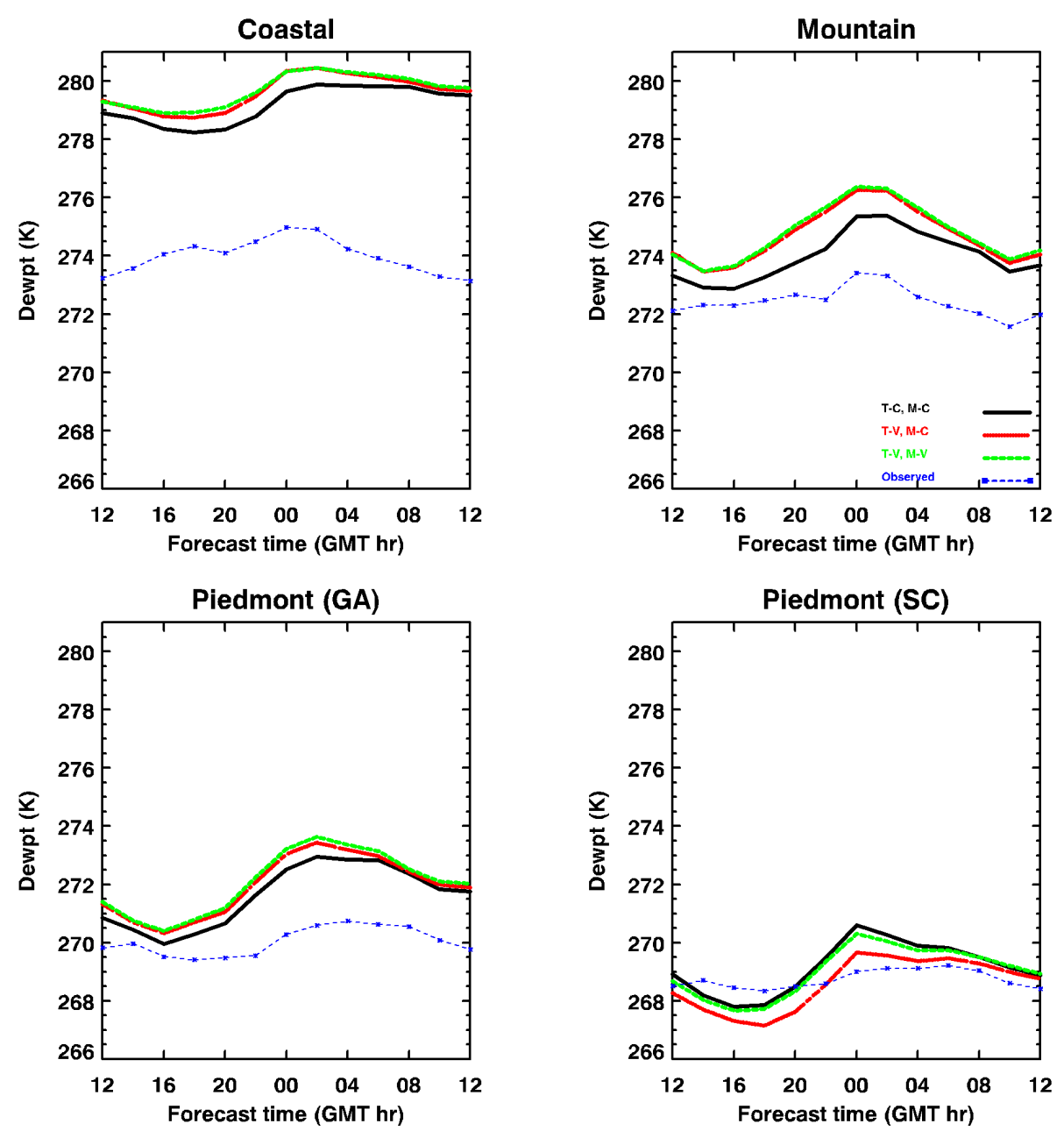

Figure 15: Dewpoint temperature as a function of forecast time in 2-hr increments for 1-31 December, 2000 as observed and simulated for each region. The average within each region is over the 6 NWS stations and over all 31 days. If observed data are missing, then results for that station and time are discarded.

T-C, M-C = Constant soil texture field, constant initial soil moisture field,

$\mathrm{T}-\mathrm{V}, \mathrm{M}-\mathrm{C}=$ Variable soil texture field, constant initial soil moisture field,

$\mathrm{T}-\mathrm{V}, \mathrm{M}-\mathrm{V}=$ Variable soil texture field, variable initial soil moisture field 


\section{APPENDIX: Modification to the RAMS Code}

RAMS, version $3 \mathrm{a}$ is written in Fortran 77 and contains a series of modules consisting of subroutines and functions. Several of these modules had to be modified to ingest the spatially variable soil texture and soil moisture.

Previously a constant value was assumed for soil texture throughout the RAMS domain. Although a variable exists in RAMS (SLTEX, a 2-dimensional variable) for soil texture, a constant value is assumed everywhere based on input through an input file specification (NSLCON). The soil moisture for each soil model level (SLMSTS, a 3-dimensional variable) is also often assumed constant at each level through an input file specification (SLMSTR).

The following RAMS modules have been modified.

ruser3a.f: This module contains changes in subroutine SRFINT, specifically to entry SOILINIT. Within this section, a new subroutine is called (SOILTXT), which reads in and assigns soil texture values to $\operatorname{SLTEX}(\mathrm{I}, \mathrm{J})$. This affects soil moisture and other properties determined in the module 'rsurf3a.f'. Also within the subroutine is the procedure for inputting soil moisture (either for the AVN or Eta model output) and interpolating it to the RAMS polarstereographic grid.

rsoiltxt.f: This routine (SOILTXT) is called from subroutine SRFINT and reads in the soil texture data from the $5^{\circ} \times 5^{\circ}$ blocks. Water values (see Table 4) are assigned a soil texture of ' 1 ' with the knowledge that inclusion of these soil texture values in land-surface calculations is eliminated because the land-percentage value is equal to 0 .

rnest3a.f: A change has been made to subroutine PRGINTRP, which makes calls to generate soil texture plots. The two-dimensional latitude and longitude arrays must be passed into subroutine PIXFIL_TXT for plotting purposes.

rvari3a.f: Changes were made in subroutine VARMISC. The variables for latitude and longitude are passed for plotting. Calls to SOILINIT are also made here.

rhhi3a.f: This routine is only called for horizontally homogeneous grid fields. Again, calls are made to entry SOILINIT require passage of RAMS latitude and longitude grids.

It should be noted that once the RAMS code is compiled, generating the surface files and initial/lateral boundary conditions is done as before. When the model simulation commences forward from the initial time, changes to soil texture and soil moisture are introduced. 